\title{
A DIFÍCIL CONSTRUÇÃO DE UM SISTEMA DE GOVERNANÇA PARA O AQUÍFERO GUARANI
}

\section{DIFFICULT CONSTRUCTION OF A GOVERNANCE SYSTEM FOR THE GUARANI AQUIFER}

Karina Lilia Pasquariello Mariano'

Maria Luisa Telarolli Leite ${ }^{2}$

\begin{abstract}
RESUMO: Este trabalho discute a construçăo de um sistema de governança para - Aquífero Guarani, uma das maiores reservas de água subterrânea do mundo, compartilhado por Argentina, Brasil, Paraguai e Uruguai. Embora a questâo das águas subterrâneas seja estratégica no atual cenário internacional, nem sempre essa importância se traduz numa institucionalizaçáo adequada para o tratamento dessas águas, o que verificamos no caso do Acordo para o Aquífero Guarani assinado em agosto de 2010. Considerando que o Acordo do Aquífero Guarani possui em seu âmbito a base para que se pense na construçăo de um sistema de governança entre os países partes do Acordo, a hipótese deste trabalho é de que as preocupaçôes com a salvaguarda da soberania e dos interesses nacionais dos países detentores da reserva desestimula os governos a uma maior preocupaçáo com a institucionalizaçâo desse Acordo. Para tal, analisamos comparativamente o processo de ratificaçăo na Argentina e Uruguai desse Acordo, e os debates suscitados nos congressos brasileiro e paraguaio.
\end{abstract}

PALAVRAS-CHAVE: Governança. Águas Transfronteiriças. Aquífero Guarani.

ABSTRACT: This work discusses the construction of a governance system for the Guarani Aquifer, one of the largest underground water reserves in the world, shared by Argentina, Brazil, Paraguay and Uruguay. Although the matter of groundwater is strategic in the current international scenario, this importance does not always translate into adequate institutionalization for the treatment of these waters, as

1 Professora Associada da Universidade Estadual Paulista Júlio de Mesquita Filho (UNESP/ FCLar) e professora no Programa de Pós-graduaçâo em Relaçōes Internacionais San Tiago Dantas - Unesp, Unicamp e PUC-SP. Na Unesp/ FCLar coordena o Grupo de Estudos Interdisciplinares em Cultura e Desenvolvimento (GEICD), que integra a Rede de Pesquisa em Política Externa e Regionalismo (REPRI). Integra o Grupo de Reflexión sobre Integración y Desarrollo en América Latina y Europa (GRIDALE). karina.mariano@unesp.br

2 Doutoranda em Geografia Humana pela Universidade de Săo Paulo (USP) e Mestre em Relaçóes Internacionais pelo San Tiago Dantas - Unesp, Unicamp e PUC-SP. É membro da do Observatório de Regionalismo vinculado à Rede de Pesquisa em Política Externa e Regionalismo (REPRI), da Waterlat - Gobacit, na área de águas transfronteiriças e do Grupo de Geografia Política e Meio Ambiente da USP. lutelarolli88@gmail.com 
we have seen in the case of the Guarani Aquifer Agreement signed in August 2010. Considering that the Guarani has the basis for thinking about the construction of a system of governance between the countries parties in the the Agreement, the hypothesis of this work is that the concerns about safeguarding sovereignty and the national interests of the reserve countries discourage governments to a greater concern with the institutionalization of this Agreement. To do so, we comparatively analyze the ratification process in Argentina and Uruguay of this Agreement, and the debates raised in the Brazilian and Paraguayan congresses.

KEYWORDS: Governance. Transboundary Waters. Aquifer Guarani.

\section{INTRODUÇÃO}

De acordo com relatório do Internationally Shared Aquifer Resources Management (ISARM), existem 592 aquíferos transfronteiriços no mundo, incluindo corpos hídricos subterrâneos, como definido pela Diretiva para Água da Uniāo Europeia (ISARM, 2015). Deve-se lembrar que as águas subterrâneas sâo a forma mais abundante de água doce do mundo, um recurso que se torna cada vez mais escasso e cuja gestâo envolve a necessidade de uma governança efetiva para a água de uma maneira geral e, especialmente, para os recursos subterrâneos (GLOBAL FOOTPRINT NETWORK, 2018). Essa questăo é particularmente importante no caso brasileiro, como ficou evidente na crise hídrica vivida no estado de Săo Paulo em 2014.

A água já era tema de conferências desde a década de 1970, mas foi em 1992 que seu papel no cenário internacional ganhou maiores contornos, com a realizaçáo da Conferência das Naçôes Unidas para Meio Ambiente e Desenvolvimento (Rio-92) que teve como desdobramento, a realizaçăo de outras importantes conferências acerca de temas ligados ao meio ambiente, como diversidade biológica, mudanças climáticas. Devemos lembrar que a Agenda 21 foi lançada durante a Rio-92, envolvendo a definiçăo de metas sobre questóes ambientais e de desenvolvimento, consideradas primordiais para os países cumprirem nos anos seguintes na busca por um futuro sustentável. Em seu capítulo 18, a Agenda 21 abordou especificamente a questăo de recursos hídricos.

Ainda no ano de 1992 foi realizada a Conferência Internacional para Água e Meio Ambiente, em Dublin, que indicou a execuçăo de programas e metas relacionadas à água para os países, com controle periódico no âmbito interno e externo. Essa Conferência apresentava o aproveitamento e gestăo das águas doces em uma gestăo multiescalar, com apoio dos diversos níveis aliados a campanhas, investimento e transformaçóes institucionais. As águas subterrâneas e aquíferos também foram contemplados nessa forma de gestâo, pois já no primeiro princípio da Declaraçâo de Dublin, fica prevista sua gestăo (VILLAR, 2015).

No entanto, o marco internacional fundamental para o tratamento hídrico e que vem sendo adotado no ordenamento jurídico de grande parte dos países, é a Resoluçâo 64/292, na qual a Assembleia Geral das Naçóes Unidas declarou a água limpa e segura e o saneamento um direito humano essencial para que se possa assegurar a vida e os demais direitos humanos. No ano de 2015 foi lançada a Agenda 2030, que conta em seu âmbito com os 17 Objetivos do Desenvolvimento Sustentável (ODS); entre eles, o 
sexto trata especificamente de água e saneamento, associando a sustentabilidade desse recurso e ao seu papel enquanto direito humano fundamental. 0 objetivo 6.5 coloca "Até 2030, implementar a gestâo integrada dos recursos hídricos em todos os níveis, inclusive via cooperaçăo transfronteiriça, conforme apropriado" (ONU, 2018).

No que se refere às águas subterrâneas, elas ainda carecem de tratamento apropriado no cenário internacional. Em 2008 com a Resoluçâo 63/124 da Assembleia Geral das Naçōes Unidas, referente aos aquíferos transfronteiriços, o tema passou a contar com diretrizes, mas sem que seu caráter seja vinculante. Os arranjos informais e ausência de legislaçâo específica (MECHLEN, 2016); lacunas no tratamento da governança internacional (RIVERA; CANDELA, 2018; VILLAR, 2015), entre outros fatores fazem das águas subterrâneas um tema que carece de maior robustez, ainda que a percepçâo e pesquisa tenha crescido.

A partir do exposto, discutiremos a construçâo de um sistema de governança para o Aquífero Guarani e sua dificuldade de concretizaçăo. Iniciamos nossa análise com a apresentaçấo dos instrumentos para governança e institucionalidade da água de uma maneira geral e, mais especificamente, para as águas subterrâneas. Em seguida, discutimos sobre o texto do Acordo do Aquífero Guarani, com especial ênfase aos artigos que permitem delinear uma governança para esse recurso pelos países detentores e, por fim, analisamos os processos de ratificaçâo e discussóes parlamentares realizadas nos Estados parte do Acordo, evidenciando os desafios para o avanço desse documento internacional.

\section{GOVERNANÇA PARA ÁGUA E A INSTITUCIONALIDADE DAS ÁGUAS SUBTERRÂNEAS}

A governança em termos gerais passa a ser amplamente discutida a partir dos anos de 1980, mas em relaçâo à temática da água năo houve discussōes densas sobre o tema antes de 2000; até entâo, falava-se em gestăo sustentável da água e gestăo integrada, mas náo se tratava de algo a longo prazo. Outro problema é a apropriaçáo de ferramentas da governança global para tratar da questâo da água. As análises demonstram que essa transposiçăo se mostra difícil e cheia de perigos; assim como os instrumentos nem sempre sâo aplicáveis e confiáveis para as realidades de todos os países, eles também năo se mostram efetivos para governança da água.

Held e Mcgrew (2002) entendem a governança como um esquema no qual o Estado já năo está só, mas preso em uma rede complexa de regimes, instituiçōes e organizaçóes internacionais, tanto públicas como privadas. Nesse quadro o Estado é ator chave, mas năo mais essencial. Complementar a essa definiçăo, Oran Young (2003) entende a governança como o funcionamento de regras de um jogo, as quais săo definidoras de práticas sociais, pois atribuem papéis e permeiam a interaçâo entre os atores e as diferentes dimensóes da atividade humana, a fim de solucionar controvérsias e facilitar a cooperaçăo em temas de interesse mais abrangente, como a água.

Na década de 1970, com a realizaçăo da Conferência de Mar del Plata, iniciaram-se os delineamentos para a governança dos recursos hídricos. Em seu Plano de Açăo aparece o primeiro arranjo institucional de organizaçōes internacionais ligadas, em sua 
maioria, ligadas à ONU, que se relacionavam aos múltiplos aspectos da água. Arranjo composto pelo Programa das Naçóes Unidas para o Desenvolvimento (PNUD), Banco Mundial, Organizaçaáo Mundial de Saúde (OMS), Organizaçâo das Naçôes Unidas para Alimentaçăo e Agricultura (FAO), Organizaçăo das Naçôes Unidas para a Educaçăo, a Ciência e a Cultura (UNESCO), Agência Internacional de Energia Atômica (AIEA), Secretaria Geral da ONU e outras diversas agências (VILLAR, 2015).

De acordo com Biswas e Tortajada (2010), entre as décadas de 1980 e 1990, as questōes que se relacionam à governança da água passaram a atrair mais atençâo, o que levou a um maior espaço da água nas agendas políticas e trouxe uma melhora das práticas e instrumentos para governança. Por meio de diversos diálogos em seu âmbito e da visăo predominante de gestấo integrada para água na década de 1990, contida nos documentos internacionais feitos para o tema, cunhou-se a ideia de Integrated Water Resource Management (IWRM) que considera ser possível chegar a uma distribuiçăo satisfatória de água, ambiente sem sobreposiçóes e duplicaçăo de funçóes, descentralizaçăo e, especialmente, algo que será visto com frequência nessa seçăo que săo os instrumentos de financiamento econômico (GLOBAL WATER PARTNERSHIP, 2003), como forma de garantir padrōes responsáveis por uma "boa governança" para água, ou seja, os modelos neoliberais de governança para áreas comerciais e econômicas sâo transpostos, também para a água.

A Global Water Partnership (GWP), ao elaborar texto sobre uma governança para água, em 2003, sugeriu que se ultrapassem apenas os aspectos físicos da água e se volte aos políticos, sociais e administrativos. A GWP é instrumento referencial de governança e busca integrar em um mesmo tema de interesse: políticos, sociedade civil, instituiçōes, usuários de água, ou seja, busca sistemas de governança integrados, tal qual apregoado nas conferências internacionais, para que melhorias sejam alcançadas.

O grande desafio posto é a necessária percepçăo de que năo existem modelos prontos de governança que possam ser integralmente transportados para as mais diversas realidades e recursos (BISWAS; TORTAJADA, 2010). Os instrumentos também năo se mostram eficazes, săo falhos e a lógica essencialmente econômica predominante nesses instrumentos omite certas questôes fundamentais para a governança hídrica. Ademais, ainda que se criem instrumentos para governança hídrica, eles nâo seriam capazes de dar conta das especificidades de cada circunstância que o uso de recursos hídricos encontra em cada país ou regiăo.

Um exemplo é o relatório divulgado pela Organizaçăo para Cooperaçăo e Desenvolvimento Econômico (OCDE), de 2010, o qual apresenta evidência empírica sobre as principais falhas de governança que dificultam a formulaçâo e a implementaçâo de políticas da água. $\mathrm{O}$ documento sugere um conjunto de respostas e boas práticas para superá-las. A governança multi-nível é colocada como o melhor modelo, que deveria ser adaptado às especificidades territoriais, reconhecendo que a governança é altamente dependente do contexto e que é importante ajustar as políticas da água às diferentes realidades. Além disso, o citado relatório enfatiza a necessidade de que as decisóes sejam tomadas de baixo para cima, de forma inclusiva, para o desenvolvimento de políticas eficazes no setor da água (OCDE, 2015). O relatório também problematiza a aplicaçăo do conceito de IWSM, que tem gerado resultados díspares em vários países.

Entretanto, o documento da OCDE coloca as "boas práticas" com um modelo pronto 
e associado ao financiamento e prestaçáo de contas, para identificar o que constitui uma melhora na governança. O financiamento continua sendo base para criar os princípios para uma melhor governança e outro ponto problemático do texto é a pauta no Fórum Mundial das Águas, que é uma instância pouco inclusiva para a discussăo e para o aprimoramento dos projetos hídricos, ainda muito baseada nas grandes organizaçóes mundiais como UNESCO e International Hydrological Programme (IHP), mecanismos conhecidos para a gestăo entre os anos 1990, mas que năo enfatizam a realidade e as experiências atuais.

A visāo de governança como neutra é algo que as instituiçōes internacionais apregoam, mas na prática, prevalece é a visáo instrumentalizada de governança da água como a melhor política de gestăo para os recursos hídricos, sem que haja o necessário debate para a formulaçâo dos objetivos e princípios a serem adotados. A visâo pretensamente neutra desses marcos busca imprimir a forma com a qual se lida com a água no cenário internacional, uma visăo racional e econômica. A água, entâo, passa de dever do Estado para problema do mercado (VILLAR, 2016; RIBEIRO, 2008).

Adotar uma visâo mais ampla e inclusiva de governança permite pensar também em uma gestăo mais afinada, pois o problema de acesso e distribuiçăo da água é intrínseco ao processo de tomada de decisâo, que se refere ao grupo de atores que decide, com base em seus interesses, valores e princípios sobre os recursos hídricos, seu acesso, sua gestāo (SANT'ANNA, 2011).

Existem diversas formas de pensar a governança da água, uma delas é a partir do âmbito local. Outros enfatizam o nível nacional para a tomada de decisáo, assim como também está presente a ideia de que a forma mais adequada para tratar esses recursos seria a partir de sua bacia hidrográfica, ou, por fim, como foi visto, pela governança global, que engloba as demais abordagens dentro de uma rede mais ampla (PAHL-WOSTL et. al., 2008). Uma organizaçâo que se destaca na área de recursos hídricos e que esteve presente na implementaçăo do Projeto de Proteçấo Ambiental e Desenvolvimento Sustentável do Sistema Aquífero Guarani (PSAG) é a Global Environmental Facility $(\mathrm{GEF})$, o qual funciona como uma instituiçăo que tem dado o suporte financeiro e técnico, em parceria com outras instituiçôes, para projetos de gestăo dos recursos hídricos que apresentem uma importância global. A maioria dos projetos apoiados pelo GEF demonstraram ser melhor sucedidos nas áreas de construçâo de uma visâo compartilhada da bacia e na criaçăo de capacidade e instituiçôes de governança.

No entanto, existe uma preocupaçăo de que o Programa de Águas Internacionais do GEF oriente-se apenas por projetos, sem que estes se transformem em políticas de longo prazo (CHEN et al., 2013). O caso do Aquífero Guarani pode ser um exemplo, uma vez que durante o PSAG, financiado pelo GEF, houve uma série de iniciativas para a cooperaçấo e troca de conhecimento, entretanto, após seu fim e com a assinatura do Acordo do Aquífero Guarani, as iniciativas regionais estăo estagnadas (HIRATA; SINDICO; MANGANELLI, 2018). Outra crítica ao GEF é que seus projetos seguem molde semelhante nas mais diversas regiōes, algo problemático se pensarmos que cada recurso tem sua composiçâo e dinâmica própria.

Os projetos de gestăo de águas internacionais em grande escala geralmente se concentram em fomentar processos formais de cooperaçăo intergovernamental, que muitas vezes têm um impacto limitado sobre o terreno. Em contraste, os projetos de águas 
internacionais baseados na comunidade sâo muitas vezes projetos locais, individualistas e autônomos, com falta de ligaçôes e perspectivas regionais. Consequentemente, existe um descompasso entre os processos regionais e locais e seus resultados.

Vincular processos regionais com açōes locais nâo só melhoraria a eficácia de açôes locais para abordar as questôes das águas internacionais, mas também fortalece os quadros regionais. Para tanto, seria necessária a adoçăo de uma abordagem de gestâo integrada para a gestâo das águas internacionais por meio da incorporaçăo de açóes locais em estruturas regionais de gestâo de águas internacionais (CHEN et al., 2013). Segundo Villar (2017), pensar na governança deve abranger ambiente propício, com políticas, legislaçâo e financiamento adequados; funçôes institucionais com criaçăo de estrutura organizacional, capacitaçăo, avaliaçăo dos recursos hídricos, plano de gestâo integrada de recursos hídricos, instrumentos econômicos, de resoluçấo de conflitos e ferramentas de gestăo.

Há constante insistência em tratar das águas internacionais apenas por acordos e tratados, sem abordar o aspecto da gestâo em si, assim, os acordos se mostram pouco eficazes, mas continuam sendo firmados. Uma das principais razóes para a baixa eficácia é que esses Acordos săo pouco precisos quanto aos seus mecanismos de gestăo, como é o caso do Aquífero Guarani.

Em 1999, a Associaçăo Internacional de Hidrogeólogos (IAH) formou uma comissāo de investigaçâo que buscava a identificaçăo de iniciativas internacionais para a gestâo compartilhada de aquíferos transfronteiriços. O resultado de seu trabalho indicou a necessidade de criar uma rede internacional ligada ao IAH, UNESCO, FAO e UNECE, que promoveu um encontro de especialistas que propuseram um programa de aquíferos transfronteiriços de iniciativa internacional, o Internationally Shared Aquifer Resources Management (ISARM) e, junto com o apoio do GEF e do Banco Mundial, incentivou uma série de projetos sobre esses recursos, como foi o caso do Aquífero Guarani (VILLAR, 2015; ISARM, 2016).

No que se refere especificamente à institucionalidade das águas subterrâneas, esta foi tratada de forma demasiadamente abrangente nas Conferências de Mar del Plata, do Rio-92 e de Dublin, entre outros importantes marcos ambientais e hídricos, como as Normas de Helsinque e de Seoul referentes à água doce que citavam águas subterrâneas, mas nâo possuíam caráter vinculante. A partir da A Convençâo sobre o Direito Relativo à Utilizaçâo dos Cursos de Água Internacionais para Fins Diversos dos de Navegaçăo, de 1997, consideram-se as águas subterrâneas oficialmente como assunto do direito internacional, mas de forma muito ampla, e restrita a certos tipos de aquíferos e năo a todos, pois somente considerava os aquíferos ligados a corpos hídricos superficiais e excluiu aqueles que estăo confinados, ou cujas condiçôes năo permitem a recarga (como parte Aquífero Guarani e o Arenito Núbia); e os aquíferos com recarga exclusiva da chuva (VILLAR, 2012; MECHLEN, 2009; ECKSTEIN, 2005, 2017).

Portanto, as águas subterrâneas nâo estavam delimitadas em todas as suas particularidades, o que levou a certa confusăo e dificultou a aplicabilidade e gestăo dessas águas. Ao perceber essa lacuna, os esforços se direcionaram na criaçâo de um marco legal para a temática no âmbito da CDI (ECKSTEIN, 2005). Dessa forma, foi adotada pela Assembleia Geral da ONU em 2008 a Resoluçấo 63/124 sobre o Direito Internacional dos Aquíferos Transfronteiriços da CDI, que foi base para o Acordo do 
Aquífero Guarani. Os artigos da CDI săo os primeiros a regulamentar as águas doces subterrâneas (MECHLEN, 2009). Seus princípios săo muito semelhantes aos da Convençâo de 1997 defendendo o uso equânime e racional, preocupado em nâo causar dano significativo, e fundamentado na cooperaçăo e respeito à soberania Apesar de ser importante avanço para os aquíferos no cenário internacional, seus princípios sáo demasiadamente amplos e pouco precisos (MECHLEM, 2009), algo que também pode ser transposto ao Acordo do Aquífero Guarani.

Em relaçăo aos princípios aplicáveis adotados por essa matéria no âmbito da CDI, muito do aquífero se assemelha às águas superficiais, o que pode levar à aplicaçăo de certos princípios comuns, mas existem outros pontos específicos, que demandam diretrizes específicas. Os aquíferos, quando contaminados ou poluídos, năo só săo de difícil acesso, como o reparo do dano é de alto custo. Além disso, como em partes do seu sistema, o escoamento de resíduos é mais vagaroso, năo se poderia adotar, como ocorreu, o princípio de evitar danos significativos, havendo a necessidade de explicar de forma mais explícita o que é dano e significativo, bem como, considerar o impacto do dano ao corpo superficial ligado a esse aquífero, suas zonas de carga e descarga, entre ouros fatores.

Porém, os relatórios realizados pela comissâo criada para formular o marco para aquíferos transfronteiriços, mostraram que o conceito de significativo náo necessitava de precisáo, pois o termo era flexível e relativo, sendo que as autoridades nacionais deveriam se empenhar ao máximo no controle e em evitar o dano (ECKSTEIN, 2005). Portanto, nesse arranjo mostra-se perceptível a preocupaçăo com a questăo política e legal, especialmente, com a soberania, um dos princípios desse marco.

No tocante à existência de instrumentos para institucionalizaçăo da governança de aquíferos compartilhados por mais de um país, os arranjos formais e informais têm sido modelos (ECKSTEIN, 2017), com os dois acordos de cooperaçâo técnica para monitoramento e troca de dados relacionados ao Programa de Desenvolvimento de uma Regiâo Estratégia para a Utilizaçáo do Sistema Aquífero de Arenito Nubia e a cooperaçăo técnica para o estabelecimento de um mecanismo consultivo para o Aquífero Sistema Saara Noroeste (VILLAR; RIBEIRO, 2011).

O primeiro arranjo formal no sentido de institucionalizar e instrumentalizar a governança dos aquíferos compartilhados é a Convençăo de Proteçăo, Utilizaçăo, Recarga e Monitoramento do Aquífero Franco-Suíço de Genebra, ou a Convençâo de Genebra, originado em 1978 e revisado em 2008. Esse arranjo se refere à qualidade, quantidade e recarga das águas subterrâneas e foi criado pela a Comissâo de Gestáo do Aquífero Genebra, em parceria entre França e Suíça. Apesar de seu caráter consultivo, o levantamento de informaçôes e de opiniōes técnicas possui considerável peso na área. Tudo o que é produzido pela Comissâo é altamente considerado, especialmente por conseguir manter o equilíbrio entre a soberania e a responsabilidade do Estado em seu esquema de governança, baseados na cooperaçăo e transparência. 0 documento internacional evitou criar um aparato político e legal que pudesse embasar as atitudes relacionadas à soberania dos Estados, ou das águas (ECKSTEIN, 2017). Portanto, trata-se de referencial precursor para a temática. 
Figura 1 - Governança transfronteiriça de águas subterrâneas e conceitos aninhados

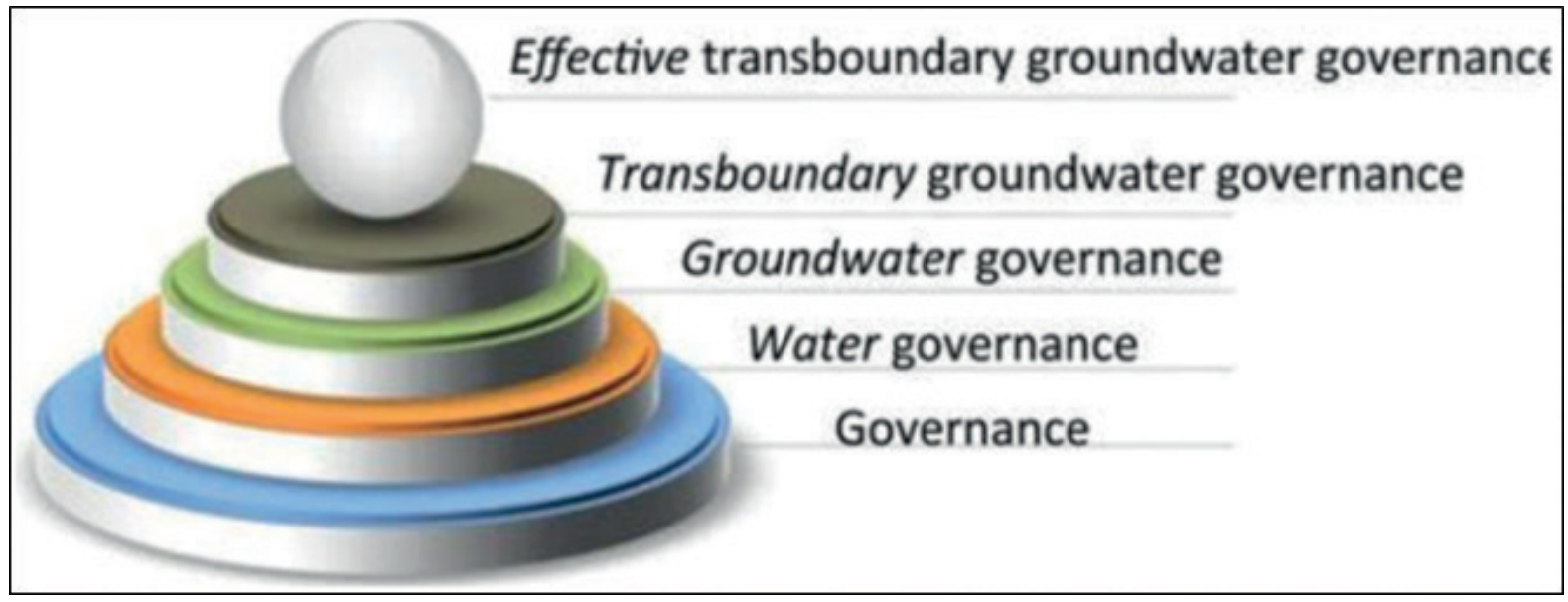

Fonte: SUGG et.al (2018).

A figura 1 sintetiza a atual estágio da governança para águas subterrâneas no cenário atual, que ainda deve superar inúmeros desafios para que seja tratada de forma adequada no contexto internacional, a complexidade desse recurso somada à ausência de ferramentas específicas fazem do tema espinhoso e enredado a outras estruturas relacionadas à governança.

\title{
20 ACORDO DO AQUÍFERO GUARANI
}

O Acordo do Aquífero Guarani é resultado de uma série de estudos e negociaçôes iniciadas nos anos noventa e influenciados por uma série de outros estudos e iniciativas referentes à governança e à gestăo das águas subterrâneas no âmbito internacional. Os estudos acerca do Aquífero Guarani já datavam da década de 1990, resultantes dos esforços da comunidade epistêmica argentina, brasileira, paraguaia e uruguaia, que passaram a desenvolver pesquisas para um mínimo conhecimento sobre a extensăo, formaçấo e conexâo hidráulica deste recurso transfronteiriço de grandes proporçôes.

\begin{abstract}
A extensăo total do SAG [Sistema do Aquífero Guarani] de $1.195 .500 \mathrm{~km}^{2}$, é compartimentada tanto em termos hidrológicos, quanto políticos e físicoambientais. Assim, os $839.800 \mathrm{~km}^{2}$ que ocorrem no Brasil, ou seja, perto de $70 \%$ da extensăo total sáo distribuídos por oito estados $\left(213.200 \mathrm{~km}^{2}\right.$ - MS; 157.600 $\mathrm{km}^{2}$ - RS; $155.800 \mathrm{~km}^{2}-\mathrm{SP} ; 131.300 \mathrm{~km}^{2}-\mathrm{PR} ; 55.000 \mathrm{~km}^{2} \mathrm{GO} ; 51.300 \mathrm{~km}^{2}-\mathrm{MG}$; $49.200 \mathrm{~km}^{2}$ - SC; e $26.400 \mathrm{~km}^{2}$ - MT). O SAG estende-se ainda por sobre 225.500 $\mathrm{km}^{2}$ na Argentina (19\%), $71.100 \mathrm{~km}^{2}$ no Paraguai (6\%) e $58.500 \mathrm{~km}^{2}$ no Uruguai (5\%) (AMORE; REBOUÇAS, 2002, p. 137).
\end{abstract}

Após quase uma década de pesquisa, em 1999, o Banco Mundial e a Organizaçâo dos Estados Americanos (OEA) se interessaram pela questăo do aquífero e aceitaram se unir aos estudos, mas desde que a elaboraçăo do projeto para o Aquífero Guarani se ajustasse aos termos do GEF (VILLAR, 2015). A partir desse momento foi percebido maior interesse pelo projeto, pensando-se em um projeto para a reserva, que se concretiza em 2003, ano de lançamento do PSAG instituído por Brasil, Argentina, Paraguai e 
Uruguai e com o apoio do Banco Mundial, GEF e OEA. O projeto tinha como objetivo a gestăo integrada e o uso sustentável do recurso hídrico para que, dessa forma, fosse possível a elaboraçâo de um quadro institucional e técnico para gestăo e preservaçâo do Sistema do Aquífero Guarani. Esse projeto foi prolongado até 2009, embora inicialmente devesse ter sido finalizado até 2007. O Banco Mundial era a agência implementadora dos recursos do GEF e a OEA era a agência executora (VILLAR, 2015).

Villar (2010) ressalta, em relaçâo à gestăo do Aquífero Guarani, que o PSAG é importante, contudo, năo fica evidente em seu texto o que o projeto chama de gestáo local, se é municipal ou do âmbito da bacia hidrográfica. Ressaltamos também que a conclusáo do projeto náo dá a devida importância a uma gestăo que contemplaria os impactos transfronteiriços, mas sim que as principais açôes de gestăo e proteçăo desse recurso deveriam estar contidas em âmbito local, algo evidente no Projeto de Açăo Estratégica (2009) que diz, de maneira clara, que as diretrizes para a gestăo deveriam ser executadas em cada Estado e em cooperaçâo entre os quatro países, na regiâo do Sistema Aquífero Guarani. Porém, “(...) no âmbito interno, as políticas nacionais para a proteçâo dos aquíferos estâo em estado embrionário, diante da falta de conhecimento técnico ou da capacidade institucional e legal" (VILLAR, 2010, p. 2).

O Mercosul foi escolhido como instância responsável pela formulaçăo de um projeto de Acordo para o Aquífero Guarani e, em 2004, o Grupo Ad Hoc de Alto Nível do Aquífero Guarani foi criado para a formulaçăo desse marco, mas o Grupo foi finalizado em 2005 sem que houvesse concordância referente ao texto do Acordo entre os países detentores do Aquífero. Após alguns anos de inatividade e o envolvimento do Parlasul na questăo, as negociaçôes foram retomadas e o Acordo do Aquífero Guarani foi assinado em 2 de agosto de 2010, na ocasiâo de uma Reuniăo da Cúpula de Presidentes do Mercosul.

O Acordo está pautado nos seguintes documentos internacionais: a Declaraçâo da Conferência das Naçôes Unidas sobre o Meio Ambiente, de 1972, a Rio-92, a Agenda 21, na Cúpula Mundial sobre o Desenvolvimento Sustentável e no Acordo Marco de Meio Ambiente do Mercosul. O Acordo visa a maior cooperaçăo pelo conhecimento científico e gestăo responsável sobre o recurso hídrico e foi o primeiro documento internacional baseado na Resoluçâo 63/124 da Assembleia Geral da ONU (ACORDO SOBRE O AQUÍFERO GUARANI, 2010).

O Acordo do Aquífero Guarani parte do regional para o internacional, o que deveria ser algo positivo, todavia, náo menciona quais políticas e diretrizes os Estados deverâo promover internamente para torná-lo efetivo (NOSCHANG, 2012), ou seja, de modo diferente do caso do Aquífero de Genebra, năo se dá ênfase aos mecanismos de gestăo, algo que deveria ser possível, uma vez que o PSAG possibilitou o mapeamento das formaçōes e áreas de maior cuidado do Aquífero, e, portanto, “(...) o tratado segue linhas gerais de gestăo conjunta de recursos hídricos transfronteiriços, mas năo observa a geografia diversa do aquífero em questăo nos quatro Estados-membros" (NOSCHANG, 2012, p.56). Dessa forma, permanecem desconsiderados importantes pontos que deveriam ser abordados no Acordo, como áreas de carga e recarga de vulnerabilidade, sua constituição geológica nas diversas áreas do Aquífero e que impactam na velocidade, qualidade, preservaçâo e resiliência dessa reserva e devem ser ponderados em sua gestăo. 
O Aquífero Guarani além de se pautar nos principais documentos ambientais internacionais, também foi o primeiro a se utilizar dos princípios da Resoluçâo 63/124, tendo a questăo da soberania enfatizada já nos seus primeiros artigos, em relaçấo à titularidade do Aquífero Guarani, o qual deveria ser gerido com base nas disposiçóes legais e constitucionais de seus Estados-parte; bem como, usa outro princípio da Resoluçâo do direito internacional, o uso equânime, racional e sustentável, o qual vem sendo reforçado por todos aqueles que vêm trabalhando com a ratificaçăo do Acordo.

Seus artigos 5 a 11 referem-se ao dano significativo, pois trata-se de evitar prejuízo sensível entre as partes e a cooperaçăo é reforçada nesses artigos para a troca de informaçôes e projetos comuns entre as partes. Apesar de perceber-se a incorporaçâo dos princípios da Resoluçâo, um deles se sobressai, que é a soberania, a qual dificulta as demais etapas de configuraçăo de um regime, que pressupóe normas, regras e procedimentos de tomada de decisăo minimante concertados, bem como um espaço e percepçâo comum desse tema como de primordial atençăo. Ademais, como Caubet (2009) analisa, há preferência por produzir um texto com artigos tradicionais para o Acordo do Aquífero, o que nâo traz maiores modificaçōes para a matéria; especialmente no que se refere à construçâo de um sistema de governança, questâo tratada na próxima seçâo.

Por fim, de acordo com Sindico (2011) esse foi o primeiro documento internacional referente à gestăo de águas subterrâneas transfronteiriças e foi demonstrativo da necessidade da aplicaçáo dos artigos da CDI, promovendo uma conexăo entre o global e o regional. Para o autor, a cooperaçăo é um dos pontos mais evidenciados no Acordo do Aquífero Guarani, especialmente no tocante à troca de informaçâo e ao direito dos países signatários de obter informaçōes adicionais sobre determinadas questōes. Sindico e Hawkins (2015) afirmam se trata de um quadro flexível de cooperaçăo, mas năo trazem maiores detalhes sobre importantes pontos de desenvolvimento do Acordo, como a criaçấo de um mecanismo de soluçâo de controvérsias, bem como de programas de cooperaçăo entre os países e a ênfase em uma legislaçáo internacional que abarcasse a gestâo desse recurso.

É perceptível que a Resoluçâo 63/124 trata apenas de diretrizes a serem adotas em situaçóes de criaçăo de mecanismos de governança e gestăo para aquíferos compartilhados, cada regiăo deve se apropriar e desenvolver documentos singulares, de acordo com as suas particularidades. O Acordo do Aquífero Guarani somente replicou o que já existia no documento da Assembleia Geral da ONU para o tema e permaneceu abrangente, pouco preciso e claro.

\section{OS PROCESSOS DE RATIFICAÇÃO}

Nem todos os países signatários do Acordo do Aquífero Guarani ratificaram esse documento. Tanto a Argentina quanto o Uruguai o ratificaram em 2012, entretanto, Brasil e Paraguai passaram respectivamente em 2017 e 2018 pela aprovaçăo recente do Acordo em seus Congressos Nacionais, mas aguardam pela aprovaçấo pelo Executivo de seus países para, entâo, entrar em vigor. A ratificaçâo é o processo de internalizaçâo da norma que, de forma resumida, ocorre após a assinatura de um Acordo, Tratado bilateral ou multilateral. O documento é encaminhado ao Poder Legislativo, o qual inicia 
o processo de análise com a escolha de relatores dentro da(s) Comissăo de Relaçóes Exteriores e/ou assuntos relacionados ao tema do documento internacional, o relator é responsável por avaliar a adequabilidade do projeto e indicar pela sua aprovaçáo ou rejeiçấo aos seus colegas da Comissăo e, posteriormente, do Plenário da Câmara dos Deputados. No caso de parlamentos bicamerais, o mesmo processo ocorre no Senado e após a aprovaçăo da matéria no Congresso Nacional, o texto deve ser designado para a aprovaçâo do Executivo e, somente após esses trâmites é incorporado no ordenamento jurídico nacional. A seguir descrevemos suscintamente como se deu esse processo nos Estados parte do Acordo do Aquífero Guarani.

A aprovaçăo da Comissión de Relaciones Exteriores y Culto argentina ocorreu no dia 22 de agosto de 2012 (APROBARÓN..., 2012) e o parecer favorável à aprovaçáo dessa comissăo e da de Intereses Marítimos, Fluviales, Pesqueros y Portuarios foi realizado no dia 11 de outubro de 2012, para entăo ser aprovado pelo Congresso Nacional no dia 31 de outubro de 2012 (ARGENTINA, 2012). De acordo com a leitura das notas taquigráficas da sessâo que tratou, entre diversas matérias, da aprovaçăo do Acordo do Aquífero Guarani, năo houve nenhuma discussấo acerca da questăo, o que, talvez, deva-se ao fato de que, no mesmo dia, foi votado o sufrágio eleitoral a partir dos 16 anos de idade na Argentina, questâo que vinha provocando polêmica no país e mobilizando a opiniâo pública (ARGENTINA, 2012). Uma vez sancionada no dia 31 de outubro, no dia 23 de novembro de 2012 foi promulgada a Ley n. 26.780, mediante o Decreto n. 2218/2012.

A partir do texto do deputado Guillermo Carmona, com base no Acordo do Aquífero Guarani, além do uso racional, equitativo e sustentável e da troca de informaçōes dos países sobre obras e aproveitamento desse recurso, está prevista a criaçáo de uma comissăo responsável por coordenar a cooperaçáo entre as partes integrantes do Sistema Aquífero Guarani (SAG); a lei n. 26.780 garante o uso e gestăo soberana da Argentina sobre o recurso; também deve ser ressaltado que naquele momento a Subsecretaría de Recursos Hídricos e o Consejo Hídrico Federal, deveriam monitorar a reserva hídrica e a implementaçăo do Sistema de Información común en los cuatro países del Sistema Acuífero Guaraní (SISAG) e manutençâo das atividades técnicas na área do Projeto Piloto Concordia/Argentina Salto/Uruguai (ACUÍFERO GUARANÍ..., 2013). Até o momento, talvez, pelo fato do Acordo ainda năo ter entrado em vigor, o SISAG ainda nâo foi iniciado.

No Brasil, além da complexidade jurídica, um aspecto que afetou a incorporaçâo do Acordo do Aquífero Guarani foi a própria morosidade do processo de ratificaçáo. 0 Acordo foi assinado em 2010, mas a aprovaçăo da representaçâo brasileira do Parlasul só ocorreu em 6 de novembro de 2015, ocasiāo na qual o Acordo foi despachado para aprovaçăo das Comissóes de Minas e Energia; de Constituiçăo e Justiça e de Cidadania; e de Defesa Nacional e Relaçôes Exteriores. A Comissâo de Minas e Energia aprovou o Acordo por unanimidade e sem discussáo, em dezembro de 2015. Segundo o relator Rodrigo de Castro trata-se de matéria “(...) relevante e trata adequadamente a exploraçâo racional e sustentável dos recursos hídricos do Sistema Aquífero Guarani, do qual - Brasil faz parte, preservando a soberania das decisōes de nosso país e fomentando a colaboraçăo e o entendimento com nossos vizinhos" (BRASIL, 2015, năo paginado).

Também a Comissăo de Constituiçăo e Justiça e de Cidadania aprovou o Acordo em 23 de agosto de 2016, com todos os votos favoráveis e sem discussâo da matéria O relatório preconiza “(...) o Sistema Aquífero Guarani como um recurso hídrico 
transfronteiriço que integra o domínio territorial soberano das quatro Partes, que deverâo exercê-lo de acordo com as disposiçôes constitucionais e legais e de conformidade com as normas de direito internacional aplicáveis" (BRASIL, 2015, năo paginado). Também foi ressaltada a necessidade do intercâmbio de informaçóes sobre práticas de gestăo e do desenvolvimento de projetos comuns, bem como a formaçăo de uma Comissăo que deve coordenar a cooperaçâo entre as partes (BRASIL, 2015).

A última Comissâo na qual o Acordo passou por aprovaçăo foi a Comissāo de Defesa Nacional e Relaçôes Exteriores, em 30 de novembro de 2016, com todos os votos afirmativos e sem discussâo. A pauta havia sido retirada 3 vezes de discussăo nos meses anteriores, mas sem justificativa aparente, de acordo com leituras das notas taquigráficas. O último passo foi a aprovaçăo pelo plenário da Câmara dos Deputados, em fevereiro de 2017; a matéria foi aprovada com todos os votos favoráveis e redaçấo do relatório final a cargo do deputado Chico Alencar.

O Acordo entâo passou para o Senado, que o aprovou no dia 2 de maio de 2017. 0 relatório da senadora Ana Amélia ressalta que a “(...) institucionalidade do Acordo sobre o Aquífero Guarani (...) é constituída no âmbito do Tratado da Bacia do Prata, e năo do Mercosul", em explicaçăo do artigo 15 do Acordo; finaliza afirmando que o Acordo "destina-se a constituir um marco fundamental da cooperaçấo regional em matéria ambiental" (BRASIL, 2017).

Na seçâo de análise do relatório da senadora, ao mesmo tempo em que se destacou o princípio da soberania e gestăo com base em normas do direito internacional de cada país, foi ressaltado que "O instrumento internacional em apreço fixa, assim, as bases de uma política comum, a ser desenvolvida pelos países signatários, voltada à preservaçâo dos recursos hídricos do Aquífero Guarani" (BRASIL, 2017).

A questăo parece dúbia no relatório e busca ser sanada com base na troca de informaçōes sobre obras sensíveis, informaçôes e cooperaçâo, mas, ainda assim, após a leitura do relatório, percebe-se que certos pontos do Acordo sâo vagos e permitem interpretaçóes, por vezes, conflitantes.

Após a aprovaçăo no Senado, ainda falta uma etapa a ser cumprida, a qual consiste em ir para o Executivo, que deve avaliar sua ratificaçăo, fato, que até o momento, năo temos informaçấo de ter acontecido (LEITE, 2018). Quanto à morosidade do processo, em entrevista realizada por Leite (2018), o deputado Chico Alencar afirmou que o trâmite de ratificaçăo é longo e a ausência de discussôes no Legislativo é natural quando se trata de matéria de consenso coletivo.

No caso paraguaio, a ratificaçăo ainda nâo ocorreu porque o período em que o Acordo tramitava nas instâncias decisórias do país, coincidiu com a crise político-institucional paraguaia, que resultou na sua suspensâo temporária do Mercosul em 2012, durante a $18^{a}$ Reuniăo do Conselho Mercado Comum, até que a ordem democrática fosse restabelecida naquele país. A decisâo estava pautada no Protocolo de Ushuaia, que em seu artigo primeiro frisa o comprometimento dos Estados Partes em manter vigentes as instituiçóes democráticas, condiçăo fundamental para o desenvolvimento da integraçăo regional (SANTOS; SANTOS, 2015).

O Acordo do Aquífero Guarani havia sido enviado ao Congresso Nacional com relatório favorável à aprovaçăo do Ministério das Relaçōes Exteriores em 07 de janeiro 
de 2011. O relatório ressaltava o espírito cooperativo do Acordo, além de frisar as dimensóes geográficas e a necessidade de um marco regulatório para a reserva compartilhada, algo que năo existia até entăo. A soberania, a troca de informaçôes e o uso racional, equitativo e sustentável, também foram destacados.

No dia 07 de junho de 2012, o Senado aprovou o Acordo do Aquífero Guarani e no dia 14 do mesmo mês, a matéria foi enviada para a Comisión de Ecologia, Recursos Naturales y Medio Ambiente. Contudo, a mudança na situaçâo paraguaia dentro do bloco parece ter sido a justificativa para que o processo de ratificaçăo fosse suspenso, pois apesar de năo ter sofrido críticas antes, em 14 de agosto de 2012 o Congresso Nacional, rejeitou o Acordo do Aquífero Guarani, sem que houvesse justificativa (PARAGUAY, 2012).

O deputado César López, que assinou o documento, afirmou que o artigo 8 do Acordo, referente o intercâmbio de informaçăo, estudos, atividades e obras que contemplam o aproveitamento sustentável do Aquífero era uma “(...) quebranta el princípio de soberanía y autodeterminación de los pueblos", uma vez que (...) el Paraguay realiza una cesión de derechos de su libertad de disponer de sus recursos hídricos" (PARAGUAY, 2012).

Recentemente, o Parlasul buscou intervir diretamente junto ao Congresso paraguaio na questăo da ratificaçăo do Acordo, considerada crucial para o tratamento adequado desse recurso. A deputada paraguaia Amanda Núnez justificou, entăo, o motivo da rejeiçấo com o argumento de que "(...) este proyecto coincidió con un momento político en el cual Paraguay estaba excluido del MERCOSUR, razón por la cual fue rechazado en este momento" (ACUÍFERO GUARANÍ..., 2017). Atualmente, o Acordo foi aceito pelo Senado e aguarda a aprovaçâo da Câmara dos Deputados.

Por fim, o caso uruguaio é o único no qual houve discussâo parlamentar acerca da matéria. O Acordo do Aquífero Guarani foi aprovado pela Asesoria de Política Comercial del Ministério de Economía y Finanzas, em outubro de 2012, seguindo em novembro do mesmo ano como projeto de lei para a Assembleia Geral, com mensagem explicativa sobre o projeto. No preâmbulo da mensagem há uma explicaçâo sobre as dimensóes físicas da reserva e seu caráter transfronteiriço, o que levou à busca por um marco regulatório entre seus titulares no Mercosul, mas o texto afirma que o Acordo năo é do Mercosul, mas sim, realizado pela Uniăo (URUGUAY, 2012). O caráter político-social também é ressaltado, pois se expressa o caráter estratégico de uma reserva como essa em um cenário no qual a água é fonte de preocupaçăo, o que torna premente a necessidade de um marco regulatório que garanta a soberania dos titulares perante essa reserva hídrica subterrânea de enormes proporçóes. O Acordo foi aprovado pela Comissáo de Assuntos Internacionais do Senado, em março de 2012, com texto explicativo de seus artigos e seguiu para a Câmara dos Deputados, onde foi aprovado em junho de 2012.

O relator, Rubén Martínez Huelmo, em sua fala favorável à aprovaçăo, frisou o papel precursor do Uruguai em considerar a água como um direito humano fundamental, por meio de mudança constitucional em 2004. A questăo da soberania e valor da reserva foi destacada pelo deputado Trobo, que também participou explicando a matéria em discussáo, colocando todos os pontos, inclusive aqueles em aberto, do texto do Acordo como a questâo da gestăo do Aquífero com base na soberania entre países com disparidade de poder e de participaçấo na reserva que se encontra, em grande parte, situada no Brasil.

O deputado também chamou a atençâo para a possibilidade de conflito, já que em meados dos anos 2000 houve o contencioso das papeleiras, referente ao Rio Uruguai 
entre a Argentina e o país. Ademais, o deputado Trobo ressaltou que dois pontos náo estăo suficientemente fechados no Acordo do Aquífero Guarani: a ausência de parâmetros legais, no caso de uma exploraçấo abusiva ou contaminaçăo por um dos países à reserva. Neste caso, o deputado sugere que deveria ser futuramente incluído algo que fosse ao encontro dos artigos 42 e 43 do Tratado entre Argentina e Uruguai de 1975 que estabelece alguma forma de responsabilizaçăo; o outro ponto colocado foi sobre o artigo 19 do Acordo do Aquífero Guarani, que diz respeito ao mecanismo de soluçôes de controvérsias, que era muito vago (URUGUAY, 2012).

O deputado José Carlos Cardoso expôs sua preocupaçăo com o fato de o Brasil ser o maior detentor do recurso e de seus estados abrigarem as zonas de recarga do Aquífero Guarani. Segundo o deputado, a inexistência no Acordo do Aquífero, de bases consistentes para um mecanismo de soluçấo de controvérsias também era algo preocupante (URUGUAY, 2012). O deputado Trobo logo enfatizou que o Executivo, no papel da chancelaria, seria notificado sobre a necessidade de um protocolo adicional ao Acordo nesse sentido. O deputado Vásquez demonstrou preocupaçâo com o uso e a legislaçâo brasileira acerca das águas subterrâneas e zonas de recarga, mais especificamente do Aquífero Guarani, pois havia uma grande assimetria entre as legislaçôes uruguaias e brasileiras nessa questăo. $O$ deputado Caram, em continuidade ao ponto levantado por Vásquez, advogou favoravelmente à aprovaçăo do Acordo e ressaltou uma visăo, por vezes, segundo ele, equivocada do Brasil, que usa a televisáo como forma de atingir em massa uma conscientizaçâo sobre o meio ambiente, os recursos hídricos e o Aquífero Guarani, lembrando que a Rio+20 seria no Brasil e que o país havia sido erroneamente estigmatizado por nâo preservar seu meio ambiente em prol do crescimento. Logo após, o Acordo foi votado e aprovado.

Por meio das notas taquigráficas, ficou perceptível a importância da questăo da soberania e da titularidade desse Acordo no cenário internacional, bem como a ressalva em relaçăo à grande porçáo do recurso estar situada no Brasil e do mecanismo de soluçấo de controvérsias amplo disposto no Acordo do Aquífero Guarani, levando em consideraçâo o conflito anterior com a Argentina.

Em entrevista realizada com o deputado Huelmo, este lembrou que o Acordo foi feito com o intuito de garantir a soberania desse recurso entre seus titulares, e assinalou que "(...) es menester recordar que organismos internacionales de crédito llegaron a plantear la posibilidad que los acuíferos fueran garantía de eventuales préstanos" (LEITE, 2018). Porém, o deputado Huelmo năo deixou de enfatizar que o mecanismo de soluçăo de controvérsias só será posto em prova, quando o Acordo entrar em vigor, ou seja, quando todos seus participantes o ratificarem, sendo inclusive para o Brasil, detentor da maior porçâo do Aquífero, uma responsabilidade "mayúscula" (LEITE, 2018).

Quanto às garantias do Uruguai, o deputado afirmou que, embora o Acordo seja precursor em buscar entre os países na regulamentaçăo e preservaçăo do Aquífero, isso năo é garantia de que futuramente, nâo haja inserçăo de novas demandas no marco. Inclusive, citou a iniciativa do país, em dezembro de 2017, na qual o Câmara dos Deputado aprovou, por unanimidade, um projeto de lei que proíbe por quatro anos o fracking ${ }^{3}$, técnica controversa de fraturamento hidráulico, que visa a extraçấo de hi-

3 A tecnologia de extraçăo de gás está embasada em processos invasivos da camada geológica portadora 
drocarbonetos. O mesmo projeto também visa a criaçăo de uma Comissâo de avaliaçâo científica e técnica que possa averiguar a aplicaçăo desta prática no território uruguaio, o que, segundo Huelmo, garantirá novas seguranças ao Aquífero (LEITE, 2018).

\section{CONSIDERAÇÕES FINAIS}

A exposiçâo realizada no presente artigo chama a atençăo para alguns pontos importantes. Em primeiro lugar, năo há um consenso internacional sobre como tratar a gestâo das reservas de águas subterrâneas compartilhadas por países. Neste caso, esbarra-se em um aspecto fundamental: a questăo da soberania. A posse compartilhada năo garante nem o uso compartilhado, e nem mesmo o compartilhamento de uma visăo sobre o tratamento a ser dados a esse recurso. No caso específico do Aquífero Guarani, encontramos um bom exemplo dessa dificuldade. Há uma clara resistência dos países em construir uma instância regional de gestăo do Aquífero. Essa resistência năo significa desinteresse pelo tema, pelo contrário, os dados demonstram uma preocupaçăo real com o assunto. $O$ problema está em como encaminhar essa questăo.

Em primeiro lugar, percebe-se uma preocupaçăo em evitar que a falta de uma resoluçâo regional crie um vácuo que permita uma imposiçăo internacional. Tal como ocorre na Amazônia, os governos reconhecem o valor estratégico das águas subterrâneas e o interesse crescente que esse tema pode assumir no futuro. Assim, a construçáo de um sistema regional legal para tratar o assunto era fundamental e estimulou a realizaçâo do acordo.

Mas a convergência entre os detentores desse recurso termina aí, porque nâo há um consenso real em como gerir o Aquífero por duas razōes básicas: disparidade e preservaçáo da soberania. A disparidade se refere à distribuiçăo desigual desse recurso entre os seus membros, pois o Brasil detém a maior parte do Aquífero e de suas áreas de recarga. A segunda razâo apontada está ligada a essa primeira, uma vez que a construçâo de uma governança regional pressupôe a institucionalizaçăo de regras a serem seguidas por todos, e à possibilidade de puniçáo em caso de descumprimento.

A puniçấo aqui é um elemento chave na explicaçăo porque pressupōe a possibilidade de que uma instância fora do Estado lhe imponha um comportamento, o que afetaria a sua soberania. Esse tipo de situaçăo é recorrentemente rejeitada pelos países envolvidos, sendo inclusive uma causa importante dos problemas vividos pelos processos de integraçáo por eles promovidos.

Ao nâo aceitarem a subordinaçâo em certos assuntos aos ditames de uma instância regional, os países do Mercosul reforçam o caráter instável de sua cooperaçâo e a desconfiança entre os participantes quanto a observância dos acordos, o que por sua vez, desestimula o cumprimento dos compromissos e alimenta esse ciclo vicioso negativo. No caso do Aquífero Guarani, o Acordo foi o limite do consenso, permitindo a sua ratificaçăo sem grandes resistências, a năo ser no caso do Paraguai, mas por questóes distintas. Contudo, a construçấo de uma governança regional para o tratamento adequado dessa reserva de água subterrânea parece ainda uma meta irrealizável no médio prazo.

do gás, por meio da técnica de fratura hidráulica, com a injeção de água, areia e substâncias químicas, podendo ocasionar vazamentos e contaminaçấo de aquíferos de água doce que ocorrem das camadas que se busca alcançar (SCHEIBE, 2013). 


\section{REFERÊNCIAS}

ACORDO DO AQUÍFERO GUARANI. International Law Association, 2 ago. 2010. Disponível em: https://www.internationalwaterlaw.org/documents/regionaldocs/ Guarani_Aquifer_Agreement-Portuguese.pdf. Acesso em: 10 jun. 2018.

ACUÍFERO GUARANÍ. El acuerdo de los 4 países fue aprobado por ley. Instituto Correntino de Agua y Medio Ambiente, Corrientes, 7 jan. 2013. Disponível em: http:// icaa.gov.ar/acuifero-guarani-el-acuerdo-de-los-4-paises-fue-aprobado-por-ley/. Acesso em: 12 dez. 2017.

ACUÍFERO GUARANÍ. El acuerdo de los 4 países fue aprobado por ley. Instituto Correntino de Agua y Medio Ambiente, Corrientes, 7 jan. 2013. Disponível em: http:// icaa.gov.ar/acuifero-guarani-el-acuerdo-de-los-4-paises-fue-aprobado-por-ley/. Acesso em: 12 dez. 2017.

AMORE, L; REBOUÇAS, A. C. O Sistema do Aquífero Guarani- SAG. Revista de Águas Subterranêas, n. 16, 2002.

APROBARÓN el Acuerdo sobre el Acuífero Guaraní. Parlamentario.com, Assunçāo, 22 ago. 2012. Disponível em: http://www.parlamentario.com/noticia-47274.html. Acesso em: 10 dez. 2017.

AQUÍFERO GUARANI. In: Anais XVI Encontro Nacional dos Geógrafos. Crise, práxis e autonomia: espaços de resistência e de esperanças- Espaço de Socializaçăo de Coletivos, XVI Encontro Nacional dos Geógrafos, Porto Alegre, 25-31 jul., 2010.

ARGENTINA. Câmara dos Deputados. Sesiones Ordinarias 2012 Orden del Día n. 1247 Comisiones De Relaciones Exteriores y Culto y de Intereses Marítimos, Fluviales, Pesqueros y Portuarios. Publicado em 30 out. 2012.

ARGENTINA. Câmara dos Deputados. 15a Sesión Ordinaria, Buenos Aires, 30 out. 2012. Disponível em: http://www.diputados.gov.ar/secparl/dtaqui/. Acesso em: 10 mar. 2017.

BISWAS, A. K; TORTAJADA, C. Future Water Governance: Problems and Perspectives. Water Resources Development, v. 26, n. 2, p. 129-139, 2010.

BRASIL. Câmara dos Deputados. Comissáo de Constituiçấo e Justiça e de Cidadania. Projeto Legislativo n. 262(mensagem n. 172, de 2015). Aprova o texto do Acordo sobre o Aquífero Guarani, firmado em San Juan, República Argentina, em 2 ago. 2010. Relator: Chico Alencar.

BRASIL. Câmara dos Deputados. Comissăo de Minas e Energia. Projeto Legislativo n. 262 (mensagem n. 172, de 2015). Aprova o texto do Acordo sobre o Aquífero Guarani, firmado em San Juan, República Argentina, em 2 de ago. 2010. Relator: Rodrigo de Castro. 
BRASIL. Itamaraty. Mercosul, [2017]. Disponível em: http://www.mercosul.gov.br/saiba-mais-sobre-o-mercosul\#CRONO. Acesso em 10 mar. 2017.

CAUBET, C.G. Os contextos normativos brasileiros em matéria de águas subterrâneas. In: RIBEIRO, W. C. Governança da água no Brasil: uma visâo interdisciplinar. Sâo Paulo: Annablume Editora, 2009, p. 213-239.

CHEN, S; PERNETTA, J.C; DUDA, A.M. Towards a new paradigm for transboundary water governance: Implementing regional frameworks through local actions. Ocean \& Coastal Management, v. 85, p. 244-256, 2013.

EARTH Overshoot Day marks the date when we (all of humanity) have used more from nature than our planet can renew in the entire year. Global Footprint Network, $1^{\circ}$ ago. 2018. Disponível em: https://www.overshootday.org/. Acesso em: 03 ago. 2018.

ECKSTEIN, G.E. Protecting A. Hidden Treasure: The U.N International Law Commission and the International Law of Transboundary Ground Water Resources. Sustainable Development Law \& Policy, Washington, v. 5, p. 5-12, 2005.

EICKSTEN, G. The International Law of Transboundary Groundwater Resources. New York: Routlegde, 2017.

GLOBAL WATER PARTNERSHIP. Effective water governance: learning from the dialogues. Global Water Partnership Technical Committee, Background Paper no.7, Stockholm, Sweden, 2003.

HELD, D.; MCGREW, A. Introduction. In: HELD, D.; MCGREW, A. (ed.). Governing globalization: power authority and global governance. Cambridge: Polity Press, p.1-21, 2002.

HIRATA, R.; SINDICO, F.; MANGANELLI, A. The Guarani Aquifer System: From a Beacon of hope to a question mark in the governance of transboundary aquifers. Journal of Hidrology: Regional Studies, 2018.

ISARM. TBA's of the World 2015. Disponível em: https://www.un-igrac.org/sites/default/files/resources/files/TBAmap_2015.pdf. Acesso em: 03 ago. 2018.

LEITE, M. L. T. A.. Acordo do Aquífero Guarani e a ótica da integraçăo regional. Dissertaçăo (Mestrado). Programa de Pós-Graduaçáo em Relaçôes Internacionais San Tiago Dantas, São Paulo, 2018.

MANFREDINI, F. N; GUANDIQUE, M. H. G; MORAES L.C. A Análise Jurídica do Acordo sobre o Sistema do Aquífero Guarani e a conservaçăo ambiental. Sâo Paulo, 2013.

MECHLEM, K. Groundwater Governance: The Role of Legal Frameworks at the Local and National Level-Established Practice and Emerging Trends. Water, v. 8, n. 347, 2016.

MECHLEM, K. Moving Ahead in Protecting Freshwater Resources: The International Law Commission's Draft Articles on Transboundary Aquifers. Leiden Journal of International Law, Leiden, n. 22, p. 801-821, 2009. 
NOSCHANG, P. G. Gestăo de águas subterrâneas e o Aquífero Guarani. Revista Eletrônica Direito e Política, Itajaí, v. 7, n. 1, 2012. Disponível em: https://siaiap32.univali.br/seer/ index.php/rdp/article/view/5641/3041. Acesso em: 12 out. 2017.

OCDE. Princípios da OCDE para a governança da água. Global Water Partnership, Suécia, 2015.

ONU BRASIL. 17 Objetivos para transformar nosso mundo. Disponível em: https://nacoesunidas.org/pos2015/. Acesso em: 10 jun. 2018.

PAHL-WOSTL, C. J.; MOSTERT, E. Tàbara, C. The Growing Importance of Social Learning in Water Resources Management and Sustainability Science. Ecology and Society, v. 13, n. 1, 2008.

PARAGUAY. Congreso Nacional. Proyecto de Ley que Aprueba el Acuerdo sobre el Acuifero Guraní. Comissiones de Ecologia Recursos Naturales y Medio Ambiente. Expediente n. S11798. Assunçấo, 14 ago. 2012.

RIBEIRO, W.C. Aquífero Guarani: soberania compartilhada. Estudos Avançados, Săo Paulo, v. 22, n. 64, 2008.

RIVERA, A; CANDELA, L. Fifteen-year experiences of the internationally shared aquifer resources management initiative (ISARM) of UNESCO at the global scale. Journal of Hidrology: Regional Studies, 2018.

SANT 'ANNA, F.M. Governança global dos recursos hídricos transfronteiriços: o papel da cooperaçâo internacional e da cooperaçăo transfronteiriça. Anais do $\mathbf{3}^{\circ}$ Encontro Nacional da ABRI, 2011.

SANTOS, R. S. S; SANTOS, R. M.. Os vinte e quatro anos do Sistema de Soluçâo de Controvérsias do Mercosul e o caso de suspensăo do Paraguai. Sequência, Florianópolis, n. 70, p. 253-279, 2015. Disponível em: http://www.scielo.br/pdf/seq/n70/0101-9562seq-70-00253.pdf. Acesso em: 20 out. 2017.

SCHEIBE, Luiz F.. Água, energia e o <gás de xisto como ameaça ambiental. Disponível em: https://rgsgsc.files.wordpress.com/2013/08/cfh_aula_inaugural_2013_scheibe.pdf. Acesso em: 12 mar. 2017.

SINDICO, F.. The Guarani Aquifer System and the International Law of Transboundary Aquifers. In: International Community Law Review, Londres v. 13, n. 3, p. 255-272, 2011.

SINDICO, F.; HAWKINS, S. The Guarani Aquifer Agreement and Transboundary Aquifer Law in the SADC: Comparing Apples and Oranges? Review of European, Comparative \& International Environmental Law, v. 24, n 3, p.318-329, 2015.

SUGG, Z.; VARADY, R. G.; GERLAK, A. K.; GRENADE, R. Transboundary groundwater governance in the Guarani Aquifer System: reflections from a survey of global and regionals experts. Water International, v. 40, n. 3, 2015, p. 377-400. 
URUGUAY. Câmara de Representantes. Sesión del día martes. Montevidéu, 12 jun. 2012. Disponível em: http://www.diputados.gub.uy/wp-content/uploads/2012/12/ C1427_026_2012.pdf. Acesso em: 11 mar. 2017.

VILLAR, P.C. Aquíferos transfronteiriços: governança das águas e o Aquífero Guarani. Curitiba: Juruá, 2015.

VILLAR, P.C. Governança da água na América Latina. Săo Paulo: Ana-Unesp, 2017.

VILLAR, P.C. International cooperation on transboundary aquifers in South America and the Guarani Aquifer case. Revista Brasileira de Política Internacional, v. 59, n. 1, Brasília, 2016.

VILLAR, P.C. Governança dos riscos e os aquíferos transfronteiriços. GEOUSP, Ediçâo Especial Recursos Hídricos, Sáo Paulo, n.31, p. 93-107, 2012.

VILLAR, P.C.; RIBEIRO, Wagner Costa. The Agreement on the Guarani Aquifer: a new paradigm for transboundary groundwater management? Water International. v. 36, n. 5, p. 646-660, 2011.

YOUNG, O. R. Environmental Governance: The Role of Institutions in Causing and Confronting Environmental Problems. International Environmental Agreements: Politics, Law and Economics, Netherlands, vol. 3, p. 377-393, 2003. 